\title{
Explaining Africa's Debt: The Journey So Far and the Arithmetic of the Policymaker
}

\author{
Joseph Atta-Mensah1, Muazu Ibrahim1,2,3,4 \\ ${ }^{1}$ Macroeconomic and Governance Division (MGD), United Nations Economic Commission for Africa (UNECA), Addis Ababa, \\ Ethiopia \\ ${ }^{2}$ School of Business and Law, Department of Banking and Finance, University for Development Studies, Wa, Upper West Region, \\ Ghana \\ ${ }^{3}$ Centre on African Philanthropy and Social Investment (CAPSI), Wits Business School University of The Witwatersrand, \\ Johannesburg, South Africa \\ ${ }^{4}$ Institute of Business Research, University of Economics Ho Chi Minh City, Ho Chi Minh City, Vietnam \\ Email: atta-mensahj@un.org
}

How to cite this paper: Atta-Mensah, J., \& Ibrahim, M. (2020). Explaining Africa's Debt: The Journey So Far and the Arithmetic of the Policymaker. Theoretical Economics Letters, 10, 409-441.

https://doi.org/10.4236/tel.2020.102027

Received: March 10, 2020

Accepted: April 26, 2020

Published: April 29, 2020

Copyright $\odot 2020$ by author(s) and Scientific Research Publishing Inc. This work is licensed under the Creative Commons Attribution International License (CC BY 4.0).

http://creativecommons.org/licenses/by/4.0/

\begin{abstract}
This paper provides a trajectory of Africa's debt levels over the past decades. We observe that, the continent's debt-to-GDP is rising and approaching levels that could potentially cause distress and reverse economic gains registered over the period. While Africa's growth prospects are promising, the real interest rates could be rising in the future due to slowing growth in emerging markets and tighter global financial conditions. With the interest rate-growth differential as the main drivers of overall debt dynamics, we argue that, African countries should aim at high real growth rates as a key element of their debt sustainability strategy. Overall, this paper recommends that policymakers could reduce the debt-to-GDP ratio by accelerating growth and improving primary balances.
\end{abstract}

\section{Keywords}

Debts, Distress, Africa, Interest Rate, Sustainability

\section{Introduction}

Most countries need substantial financial resources to support its development agenda. Given the challenges of mobilizing internal resources, countries have to depend on external borrowing to fund its development projects. The economic literature clearly demonstrates that public capital and infrastructure, which are essential for the socio-economic development of a country, will boost economic 
growth. This is because the scaling-up of productive public investments, through massive borrowing, while increasing debt ratios in the short run, can lead to higher growth, revenues, and exports and consequently lower debt-to-Gross Domestic Product (GDP) ratios in the long-run.

Indeed, there are several channels that explain why increases in public capital could positively affect economic growth (Agénor, 2011, 2012). First, investments in public capital yield positive productivity and cost-saving effects. This is because public capital raises the productivities of labour and private capital as well as lowers the unit costs of capital (Mustapha \& Prizzon, 2015). Second, public capital increases the rate of return on private capital. Third, increases in public capital requires domestic financing and, therefore, displaces private investment. Fourth, a "Dutch vigour" effect, where higher public capital can raise the total factor productivity through positive learning-by-doing externalities.

Unfortunately, public investments have not always resulted in increase in the stock of public capital. This is partly due to the reason that their desired outcomes depend crucially on the "efficiency" of public investments as some of the spending are wasted or spent on poor (infra-marginal) projects with low returns. In addition, absorptive capacity constraints, such as coordination problems or supply bottlenecks during the implementation phase of public investment projects, may result in large costs overruns that adversely affect the budget. Ultimately, both efficiency and absorptive capacity, play key roles in determining the final impact of public investments on growth, and consequently a country's repayment capacity of the borrowed funds to support capital investments.

The focus of this paper is to examine the current rising levels of debt in Africa and make recommendations for addressing the challenges emanating from debt overhang. We make two key contributions to the existing literature. First, we provide a more nuanced and in-depth details into the trajectory of debt dynamics in Africa while linking such dynamics to an existing theoretical literature. Second, relying on recent dynamics in the international financial architecture, this study proffers useful and practical recommendations for policy.

The scheme of the paper is as follows: Section 2 reviews Africa's debt. Section 3 examines factors that trigger debt crisis. Section 4 presents an analysis of the budget constraint faced by the policymaker concerning issuances of debt. Section 5 discusses debt management issues. Section 6 concludes by providing key policy recommendations.

\section{Overview of Africa's Debt}

The debate on debt sustainability is increasingly gaining traction especially among donors, multilateral banks and policymakers following the rise in the debt of African countries in recent years. The sharp rise in debt reminds us of the debt crisis of the 1990s when the Multilateral Debt Relief Initiative (MDRI) was adopted for the outright forgiveness of debt owed by a group of 36 low-income poor countries. The MDRI was conditioned on sound economic management 
and poverty reduction strategies as well as assist countries to achieve the then Millennium Development Goals (MDGs). Prominent of the debt relief was the Heavily Indebted Poor Countries (HIPC) initiative instituted by the International Monetary Fund (IMF) and World Bank in 1996 to address debt overhang in the poorest countries of the world. Following this initiative, 29 African countries were among the low-income countries to benefit from this debt relief.

Available data shows that the percentage of Africa's debt-to-GDP is rising very fast. Taking an average over three-year periods, we find that between 2015 and 2017, while Africa's debt as a share of GDP stood at 56.58 percent which is higher than the 55 percent debt-to-GDP ratio suggested by the IMF (see Table A1 in Appendix), it is slightly below the debt benchmark ratio of 60 percent of GDP prescribed by the African Monetary Co-operation Programme (AMCP). Indeed, between 2015 and 2017, about half of the African countries had debt-to-GDP ratios above 50 percent (see Table 1). Furthermore, with the exception of Cabo Verde and the Gambia, all Member-States of ECOWAS registered debt-to-GDP ratios far less than the convergence requirement of 70 percent. Figure 1 shows, by the end of 2017, that Cabo Verde, Republic of Congo,

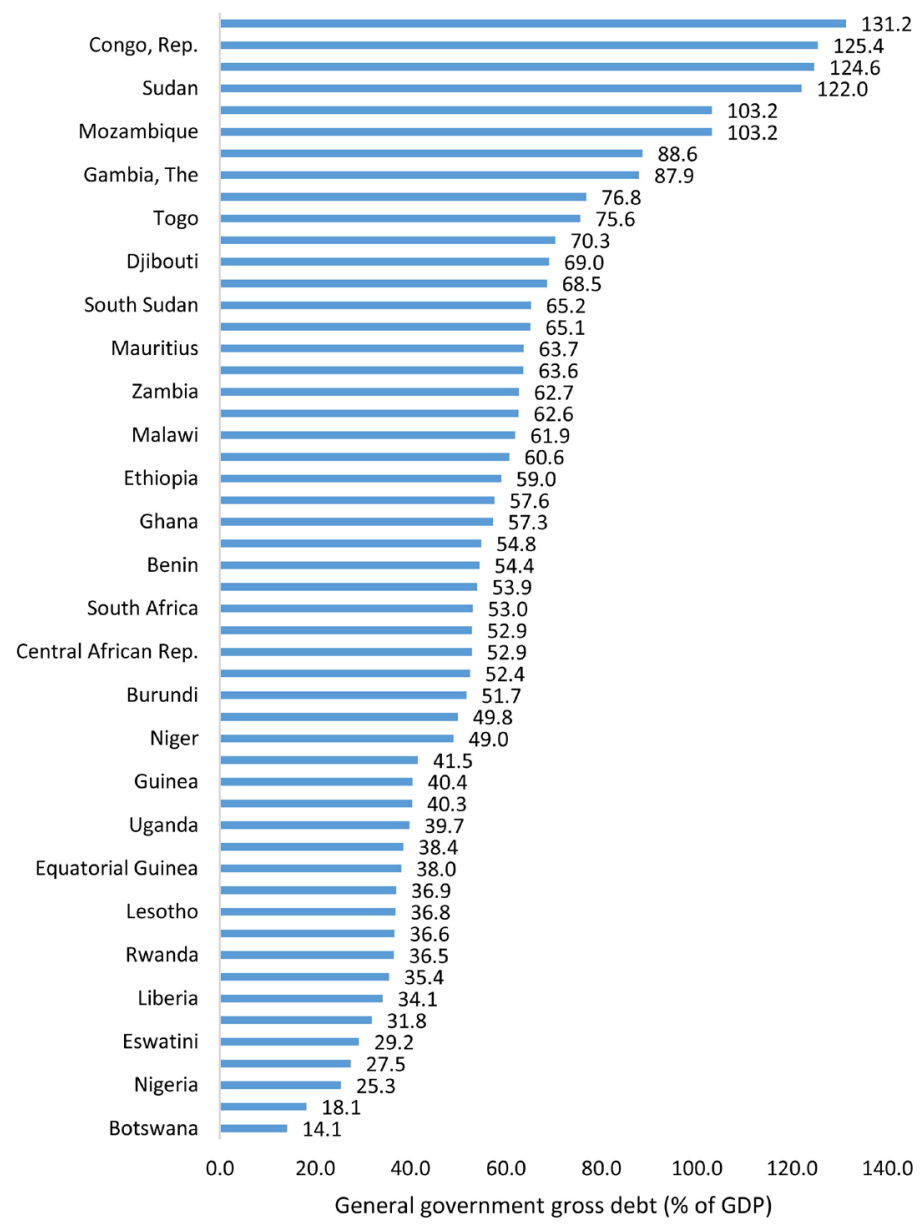

Figure 1. Total debt-to-GDP ratios of African countries in 2017. Source: Authors' calculations based on data from World Bank. 
Table 1. Percentage of African countries' debt as share of tax receipts.

\begin{tabular}{|c|c|c|c|c|c|c|}
\hline & $2000-2002$ & $2003-2005$ & $2006-2008$ & 2009-2011 & 2012-2014 & 2015-2017 \\
\hline Africa & 891.98 & 782.48 & 485.05 & 345.47 & 333.12 & 438.60 \\
\hline Algeria & 174.14 & 107.20 & 46.76 & 30.54 & 25.45 & 58.60 \\
\hline Angola & 322.98 & 139.94 & 71.55 & 123.72 & 100.22 & 202.45 \\
\hline Benin & 384.61 & 255.11 & 145.40 & 218.70 & 214.14 & 380.62 \\
\hline Botswana & 33.50 & 34.70 & 27.52 & 82.67 & 75.94 & 66.02 \\
\hline Burkina Faso & 401.44 & 369.93 & 203.23 & 241.72 & 240.26 & 311.21 \\
\hline Burundi & 1028.20 & 1171.13 & 881.07 & 280.35 & 275.49 & 353.50 \\
\hline Cabo Verde & 469.14 & 479.36 & 383.06 & 414.23 & 592.44 & 724.06 \\
\hline Cameroon & 645.80 & 502.72 & 145.35 & 133.44 & 173.47 & 319.00 \\
\hline Central African Rep. & 1270.33 & 1350.18 & 579.31 & 275.53 & 561.78 & 739.98 \\
\hline Chad & 990.61 & 585.81 & 377.20 & 510.47 & 558.46 & 817.31 \\
\hline Comoros & 786.53 & 619.15 & 532.20 & 431.97 & 237.41 & 240.93 \\
\hline Congo, Dem. Rep. & $2,609.61$ & $2,062.23$ & 1624.04 & 872.74 & 340.68 & 312.70 \\
\hline Congo, Rep. & 552.23 & 523.59 & 295.65 & 196.74 & 158.11 & 373.37 \\
\hline Cote d'Ivoire & 614.70 & 505.79 & 479.15 & 419.71 & 284.57 & 310.86 \\
\hline Djibouti & 276.25 & 294.69 & 268.94 & 240.37 & 200.90 & 302.66 \\
\hline Egypt, Arab Rep. & 550.80 & 679.44 & 532.98 & 493.21 & 565.56 & 671.50 \\
\hline Equatorial Guinea & 302.10 & 52.15 & 9.12 & 71.87 & 96.05 & 426.18 \\
\hline Eritrea & 1324.55 & 1252.32 & 1180.27 & 1027.43 & 938.72 & 968.20 \\
\hline Eswatini & 76.98 & 62.28 & 61.22 & 53.33 & 60.22 & 103.16 \\
\hline Ethiopia & 994.13 & 949.85 & 527.86 & 411.99 & 458.30 & 565.07 \\
\hline Gabon & 539.90 & 414.04 & 227.63 & 158.17 & 199.39 & 394.88 \\
\hline The Gambia & 922.56 & 971.13 & 644.68 & 508.71 & 703.29 & 947.72 \\
\hline Ghana & 607.88 & 390.98 & 202.38 & 284.28 & 397.42 & 517.46 \\
\hline Guinea & 915.10 & 921.37 & 741.95 & 650.89 & 332.92 & 430.20 \\
\hline Guinea-Bissau & 4152.30 & 4002.08 & 3324.36 & 1666.91 & 933.21 & 1024.53 \\
\hline Kenya & 380.12 & 362.21 & 276.37 & 286.94 & 304.47 & 355.94 \\
\hline Lesotho & 236.35 & 126.17 & 126.69 & 85.94 & 99.00 & 101.18 \\
\hline Liberia & $3,880.40$ & $4,533.51$ & $2,925.27$ & 500.23 & 185.13 & 285.89 \\
\hline Madagascar & $1,074.92$ & 970.27 & 354.45 & 367.00 & 366.32 & 406.29 \\
\hline Malawi & 938.95 & 798.79 & 211.49 & 218.84 & 360.19 & 420.69 \\
\hline Mali & 552.19 & 349.17 & 149.06 & 186.61 & 207.41 & 267.51 \\
\hline Mauritania & $1,605.40$ & $1,205.89$ & 502.45 & 414.47 & 394.02 & 555.89 \\
\hline Mauritius & 350.16 & 363.83 & 312.02 & 330.77 & 343.53 & 377.43 \\
\hline Morocco & 319.50 & 287.42 & 241.70 & 236.08 & 290.32 & 309.60 \\
\hline Mozambique & 826.21 & 533.17 & 309.50 & 320.84 & 405.07 & 814.39 \\
\hline
\end{tabular}




\begin{tabular}{ccccccc} 
Continued & \multicolumn{7}{c}{ (99.07 } & 97.26 & 74.01 & 68.99 & 86.87 & 143.23 \\
\hline Namibia & 944.03 & 623.80 & 190.88 & 202.12 & 237.93 & 392.69 \\
Niger & 575.86 & 360.98 & 92.74 & 133.90 & 201.31 & 258.37 \\
Nigeria & 915.21 & 743.72 & 197.45 & 160.18 & 196.15 & 293.42 \\
Rwanda & $2,601.00$ & $2,174.36$ & 969.64 & 516.19 & 497.48 & 599.79 \\
Sao Tome and Principe & 407.50 & 283.95 & 132.88 & 213.50 & 275.31 & 371.27 \\
Senegal & 662.08 & 559.08 & 544.02 & 312.70 & 255.14 & 230.82 \\
Seychelles & $2,135.11$ & $1,856.85$ & 787.32 & 585.55 & 428.84 & 662.44 \\
Sierra Leone & 168.50 & 144.48 & 119.08 & 144.41 & 185.23 & 215.70 \\
South Africa & 1851.93 & 1378.12 & 821.06 & 985.02 & $1,295.85$ & $1,446.23$ \\
Sudan & 429.55 & 399.41 & 223.60 & 234.17 & 269.07 & 320.58 \\
Tanzania & 295.38 & 273.17 & 227.75 & 207.81 & 246.81 & 317.75 \\
Tunisia & 634.93 & 602.32 & 247.99 & 205.76 & 262.68 & 351.52 \\
Uganda & 1422.64 & 797.31 & 144.41 & 131.50 & 193.59 & 405.39 \\
Zambia & NA & 205.70 & 301.11 & 317.30 & 240.66 & 308.68 \\
Zimbabwe & & & & & \\
\hline
\end{tabular}

Source: Authors' calculations based on data from World Bank.

Arab Republic of Egypt, Eriteria, Angola, Djibouti, the Gambia, Malawi, Mauritania, Mauritius, Morocco, Mozambique, Sao Tome and Principe, Seychelles, Sudan, Tunisia, Zambia have debt-to-GDP ratios over 60 percent which are very high, pushing them potentially into high risk of debt distress.

Worsening the situation for Africa is that the growth in borrowing has not been matched with increases in tax revenue. Table 1 shows that on average, Africa's debt is over four-folds of what it collects as tax revenues. Adeniran et al. (2018) suggest that the weak tax revenue stems from worsening macroeconomic conditions and continuing oil and commodity price shocks. The dwindling tax revenues threaten the ability of countries to service their rising cost of debt. Krumm (1985) indicates that the changing structure of Africa's debt is also a challenge. As compared to the past, countries are tilting towards non-concessional and domestic debt with higher interest rates. Krumm (1985) further notes that the ease to which governments in Africa have access to and control over the domestic debt market is leading to excessive public debt accumulation and macroeconomic instability. Besides facing high interest rates and debt-servicing burdens, African countries' appetite for domestic debt deny their private sectors the needed credit to support economic activities and job creation.

\section{Africa's Past Debt Challenges}

Africa has had a history of debt challenges. For most part, earlier literature (Krumm, 1985; Adeniran et al., 2018; Mustapha \& Prizzon, 2018) suggests that, Africa's debt crises started in the late 1970s when many African countries amassed 
substantial external debt to finance its public expenditure. However, weak domestic savings and declining commodity prices made it very difficult for countries to service the debt. Furthermore, countries took on additional loans to cushion the 1973 oil and commodity price shocks with the expectations that commodity prices would eventually recover. Adeniran et al. (2018) find that between 1976 and 1980, Africa's external debt grew by $187 \%$, from $\$ 39$ billion to $\$ 112$ billion.

Greene and Khan's (1990) analysis shows that commodity price shocks caused many African countries to acquire more debt in order to stimulate economic recovery through expansionary fiscal policies. However, poor management of the economy and the collapse of the manufacturing and agriculture sectors led to anaemic economic growth. Greene and Khan (1990) also suggest that new loans were not channelled towards the productive sectors but to consumption and non-export-oriented projects, which lacked the capacity to generate revenue for debt service repayments. The plight of African countries deepened as a second commodity shock in 1979 and 1980 caused a decline in the non-tradable and the export sectors. Consequently, Africa's external debt-to-export and debt-to-Gross National Income (GNI) ratios grew by $218 \%$ and $110 \%$ respectively between 1980 and 1987 (Adeniran et al., 2018). Greene and Khan (1990) also indicate that conditions further worsened for African countries as growing fiscal deficits were followed by a rise in foreign interest rates and a decline in net capital inflows, leaving many African countries unable to meet their debt service obligations.

Greene (1989) documents that the Bretton Woods institutions responded to the 1970/1980s debt overhang by creating adjustment programmes for African countries to strengthen export earnings and reduce imports and as well control the rising inflation. To tap into the funds, African countries needed to embark on structural adjustment policies, which stipulated certain economic pre-conditions. Greene (1989) indicates that these conditionality-based financial assistance programmes catalysed the granting of debt relief by bilateral creditors and commercial banks. Adeniran et al. (2018) estimate that between 1980 and 1984, the Paris and London Clubs granted $\$ 10$ billion in debt relief to some African countries that followed the Structural Adjustment Programmes (SAPs).

Unfortunately, the structural-adjustment-loans-debt-relief initiatives by the creditors did not translate into economic fortunes for African countries. Jauch (1999) reports that IMF responded again by establishing the Structural Adjustment Facility (SAF) in 1986 to provide assistance on concessional terms to low-income countries that were undertaking the SAPs. The focus of the SAPs was the restructuring and diversification of the productive base of African economies. It also aimed at achieving fiscal and balance of payments' stability, disinflation and reducing the dominance of unproductive investments in the public sector. However, Jaunch (1999) observes that the SAPs failed to achieve their desired outcomes but rather resulted in leaving behind large current ac- 
count deficits, high inflation and weak currencies across the continent. The SAPs therefore left African economies with massive unsustainable debt burdens.

In a bid to tackle the debt crisis again, the World Bank and the IMF, in 1996, established the HIPC initiative to provide debt relief for African countries in debt distress. Countries under HIPC were granted an annual debt service reduction of up to 80 percent of their debt obligations as they became due until the committed debt relief had been provided in full. To be eligible for HIPC debt relief, a country needed to have, among others 1) a debt-to-GDP ratio of 50 percent and above; 2) a debt-to-export ratio of 150 percent and above; and 3) a debt-to-government revenue ratio of 250 percent and above. Further adjustments were later made to allow more countries to qualify for the initiative through increase in the size and pace of debt relief, and link debt relief to poverty reduction. In addition, in 2005 the IMF introduced the MDRI to support the continent in achieving the Millennium Development Goals (MDGs) through full debt relief on eligible debt. Adeniran et al. (2018) observe that under the HIPC and MDRI, 36 countries of which 30 were African countries-reached the completion point, resulting in debt relief of $\$ 99$ billion by the end of 2017. It is imperative to note that the HIPC and MDRI reduced the average debt-to-GDP ratio for Africa from 104.5 percent in 2000-2003 to about 57 percent average between 2006 and 2008 (see Table A1 in Appendix).

\section{Africa's Current Debt Challenges and the Economic Environment}

An important question to ask is what are the causes of the current rise in the debt levels for Africa and whether the current economic conditions are the same as those that prevailed prior to the HIPC/MDRI initiatives and therefore the alarm bells should be sounded for an imminent debt crisis in Africa? Before we assess the drivers of the current rising levels of debt, we first tackle the second part of the question. As much there is a need for judicious management of Africa's debt, there would not be the need for the ringing of the alarming bells loudly as Africa's economic conditions are currently far better than the pre-HIPC years. Atta-Mensah $(2015,2017)$ argues that the economies of most African countries are currently embarking on transformation of their economies and are very sound that despite the severity of the global financial and economic crisis of 2007-2008, Africa did not deep into a recession but rather saw its economies significantly slowdown. The channels, through which the crisis affected Africa, included among others, plummeting trade, the drying-up of the flows of financial capital and remittances as well as threats of bank runs and weak financial intermediation. These negative influences caused Africa to register an average growth of 2 percent in 2007. The positive performance of Africa is due to the solid policies of many African countries prior to the crisis. These policies, which inoculated the African economies against the severe ramification of the crisis included low-inflationary monetary stance, prudent fiscal management (strengthened 
budget positions, reduced debt burdens and reformed tax structure), and reasonable foreign currency reserve cushion. Improved fiscal position allowed countries to also use their budgets to counteract the crisis, rather than making it worse. Fiscal policy was therefore expectedly countercyclical in many African countries at the time of the crisis. It should be said that, the fiscal cushion helped a great deal to protect the poor and vulnerable as social spending was not cut during the crisis.

It has to be noted the current size of Africa's debt as a ratio of its GDP is lower than those of other regions. Figure 2 shows that Africa's average debt, since 2010, has been substantially lower than those of Brazil, Germany, UK and the US. Figure 3 also shows that, since 2010, Africa debt-to-tax revenue has been less than those of India and the US. These observations suggest that, the debt-to-GDP indicator, African countries are in superior position than the US. Yet alarm bells are not being ringed by the Multilateral Development Banks that Germany, UK and the US are facing eminent debt crisis. Perhaps, it is assumed that their economies are better managed and therefore they have the capabilities to retire their debts more than the economies of Africa.

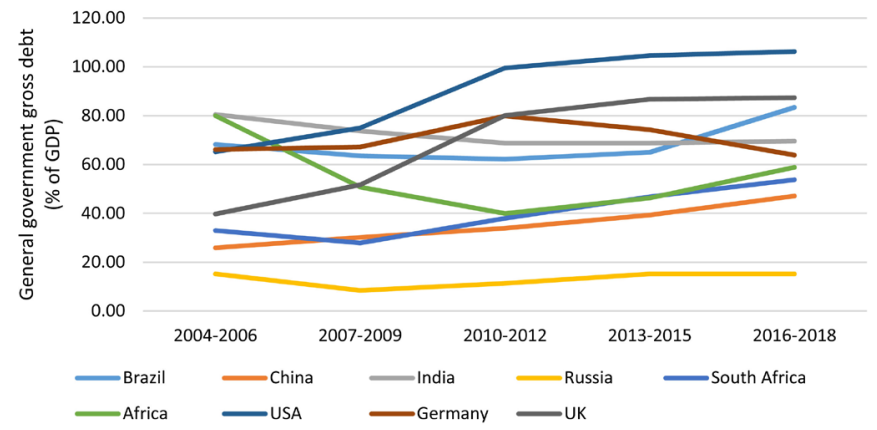

Figure 2. Total debt-to-GDP of selected countries. Source: Authors' calculations based on data from World Bank.

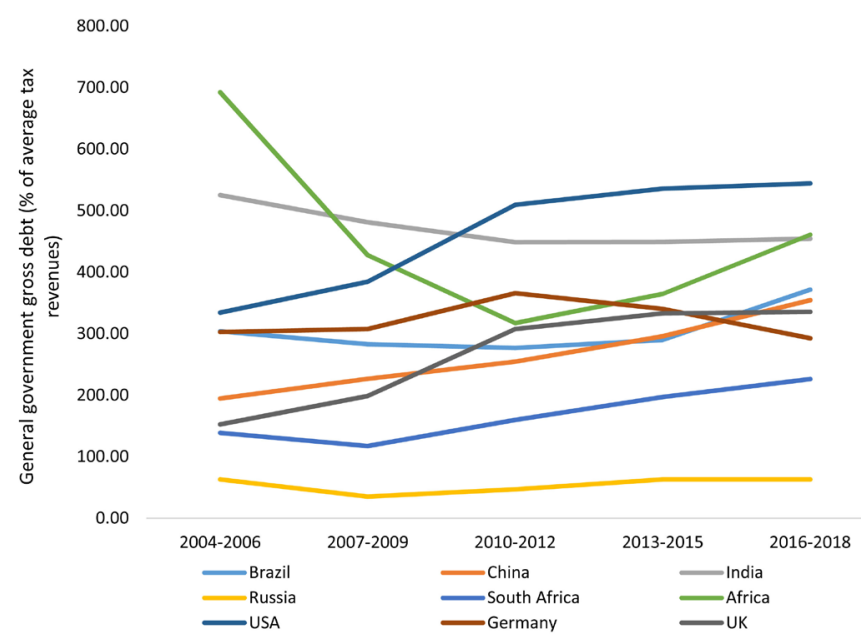

Figure 3. Total debt-to-tax-revenue for selected countries. Source: Authors' calculations based on data from World Bank. 
Despite the current robust economic performance, Africa should not rest on its laurels as it remains vulnerable to shocks from different sources. These shocks could potentially come from volatility in commodity prices, natural disasters, climate change, wars and conflicts as well as weakened flow of remittances, aid and financial flows. The challenge for Africa is to continue to pursue an agenda of strong inclusive-growth at the same time reinforcing its resilience to shocks. This requires that Africa stay on course on its pursuant of sound macroeconomic policies. Hence policy buffers must remain in place to allow for future countercyclical responses including prudent fiscal policy and the use of reserves. Social safety nets need to be strengthened as well. Social and income inequalities must also be aggressively addressed so as not to heighten tensions within the population in times of economic downturn and make shocks more destabilizing.

Experiences from other parts of the world indicate that if African countries continue their current economic performance, then the rapid growth recorded prior to the financial crisis would result in substantial structural changes within the economies of many countries. The goal of many African countries, as enshrined in their development plans or strategies, is to reach middle-income-country status by the next decade. However, moving from low- to middle-income status would not only require an increase in per capita income but also structural transformation of the economies as an important part of development.

\section{Drivers of Rising Debt}

It is the pursuit of structural transformation of their economies that might have caused the current rise in debt levels. To embark on structural transformation of the economies of Africa requires massive investments in infrastructure which must be supported by borrowing from both the domestic and external markets. Coulibaly et al., (2019) indicate that due to low domestic saving rates, African countries have had to resort to borrowing from a variety of sources, including international debt markets (Eurobond issuances), domestic markets, multilateral institutions, and Paris and non-Paris Club countries to support the growing needs for infrastructure and other economic programmes ${ }^{1}$. In recent years, China has played a significant role in the development of the infrastructure in Africa through large scale financing. It is well known that, China has supported the construction of railways, roads, power plants, ports, and other infrastructure projects in many parts of Africa. Coulibaly et al. (2019) however note that between 2012 and 2016, African governments financed over 40 percent of their own infrastructure needs. Over this period, China financed 15 percent, much more than the 3 percent from the multilateral development banks.

Africa's rising debt can also be attributed to current low global interest rate environment, forcing the private markets to search for higher yielding assets. In addressing the fallout of the global financial crisis of 2007/2008, Western central ${ }^{1}$ The African Development Bank (AfDB) estimates Africa's annual financing needs for infrastructure at $\$ 130$ billion to $\$ 170$ billion and the financing gaps at $\$ 68$ billion to $\$ 108$ billion (AfDB, 2018). 
banks embarked on quantitative easing which saw interest rates tumble to extremely low levels. The search for higher yields for private capital in frontier markets outside developed economies led to the private market lending to several African countries. A number of African countries took advantage of these non-traditional lending markets by issuing Eurobonds. The over-subscription of these Eurobonds suggests that investors do not agree with the view of an imminent debt crisis in Africa. Coulibaly et al. (2019) observe that in the last two years, Angola, Côte d'Ivoire, Ghana, Kenya, Nigeria, and Senegal have successfully issued Eurobonds with 30 years maturities.

Coulibaly et al. (2019) propose other drivers for the current rise in debt. First, they argue that the shocks of the global financial crisis and the 2014 terms-of-trade shock contributed to swelling-up the debt of many African countries. The economic downturn as a result of the global financial crisis and terms-of-trade shocks were mitigated by African countries through the accumulation of additional debts. Prior to the global financial crisis, most African countries registered primary fiscal surpluses, averaging about 3.5 percent of GDP between 2005 and 2008. Coulibaly et al. (2019) note that following the global financial crisis, the surpluses turned into deficits, averaging 1.6 percent of GDP through 2013. The 2014 terms-of-trade shock further widened the deficit to 3.2 percent, on average, between 2014 and 2017, which accelerated debt accumulation.

Another driver Coulibaly et al. (2019) point to the ballooning Africa's debt is the consequences of the depreciation of currencies. They point out that because Africa's Eurobond debt which are dominated in foreign currency (mainly in US dollar) are not hedged against exchange rate fluctuations and therefore the domestic currency value of unhedged debt increases with exchange rate depreciation. This is assertion is supported by Coulibaly and Gandhi (2018) who find that large primary deficits and exchange rate depreciation account for more than half the rise in public debt levels since 2014.

\section{Usage of the Debt}

Another important question we need to ask is what the Africa's debt is being used for. In other words, are they being used for consumption or investments needed to spur growth? In examining the rising debt levels, it is equally important for one to assess the ability of a country to repay its debt. Since the debt has to be repaid in the future, what matters most is future growth path of GDP. Coulibaly et al. (2019) suggest that most of the drivers of the increases in debt appear to be dissipating. Commodity prices are expected to rebound as economic growth is improving in parts of Africa, exchange rates have stabilized or strengthened and fiscal consolidation is under way (UNECA, 2019). Furthermore, Coulibaly et al. (2019) project debt levels to decline to 47 percent by 2023. The IMF's (2018) World Economic Outlook also projects a decline in median debt levels over the next three years. These projections indicate that, healthy 
portions of the debts are used to support economic growth rather than consumption. Furthermore, the future prospects for Africa are strong and may be part of the reasons why the capital markets are willing to lend to some African countries. It has to be recalled that a year ago, Kenya's $\$ 2$ billion bond was seven times oversubscribed. Ghana's $\$ 3$ billion bond offering in 2019 was also six times oversubscribed $^{2}$.

On the other hand, there is evidence that Africa has massive transport, energy, health and education needs, and debt is a major source of development finance. With global interest rates at historic lows, it seems too good an opportunity for Africa to miss. New lenders like China appear keen to get into the game. Commodity prices are recovering and, with 1.4 billion Indians joining the world of big spenders, commodity price might remain high for decades.

The accumulation of debt is not a bad policy in itself. Coulibaly et al. (2019) find evidence that Africa's debt has been used to stimulate both consumption and investment. Debt is an important tool for the financing of projects that supports economic development. Given the weak domestic resources, debt can be used to smooth-out economic fluctuations through the prudent use of fiscal policies. Debt must therefore be used for value-creative economic and social projects.

Blanchard (2019) makes the point that small increases in debt have bigger impact on economic output because of larger multipliers. The author observes that during the period of global financial crisis, the multipliers were higher. This was in part because the lower the ability to borrow, by both households and firms, implied a stronger effect of current income on spending, and thus a stronger multiplier. This implies that debt has stronger impact on the economy if targeted to the productive sector. Furthermore, budget deficits are needed on a sustained basis to achieve sufficient demand and output growth. This is because not only are budget deficits needed to eliminate output gaps, but, because the riskless interest rates are likely to be far below potential growth rates. Hence, the welfare costs of debt may be small or even altogether absent.

DeLong and Summers (2012) have also examined the nexus between debt and output in the presence of hysteresis ${ }^{3}$. They find that even a small hysteretic effect of a recession on later output might lead a fiscal expansion to actually reduce rather than increase debt in the long run, with the effect being stronger, the stronger the multipliers and the lower the safe interest rate. Hence, debt might be the anecdote to preventing hysteresis and addressing unemployment. Moreover, during recession, domestic resources are not sufficient to support public investments. The marginal product of capital therefore rises. Countries may therefore resort to debt to finance needed public investments.

${ }^{2}$ Olabisi and Stein (2015) find that African governments are paying 3 percentage-points more than other comparable countries to borrow from the market. Hence, there is about 300 basis points premium for African countries assessing the capital markets than other countries.

${ }^{3}$ Hysteresis means that historical rates of unemployment do influence the current and future rates of unemployment. This is because during recessions the rise in cyclical unemployment does increase the structural (natural) rate of unemployment. 


\section{Composition of Debt}

In assessing the debt levels of countries, it is important to examine the structure of the debt. The debt structure of Africa is changing. In addition to external debt, countries have created an environment to mobilize domestic debt. Also, given improvements in their economies more countries are taking up commercial debt than concessional debt. Some countries have also resorted to commodity-linked debt instrument.

Table 2 and Figure 4 clearly show that since the mid-2000, Africa, on average, has been accumulating more domestic debt. The table shows that since the pre-HIPC era of 2000, the ratio of external debt-to-GDP has been declining, registering an average of 42.36 percent between 2015 and 2017. Nevertheless, Figure 4 shows that, 10 countries have a greater share of their debt portfolio in external instruments, recording a ratio of external debt-to-GDP greater than 60 percent, with Seychelles and Djibouti topping the chart. At the same time, domestic debt is also on the rise. Coulibaly et al. (2019) find that the increase in domestic debt is due in part to the issuances of government bonds on local debt markets with commercial banks as creditors. The higher exposure of commercial banks to government debt makes those banks particularly vulnerable to debt distress.

Coulibaly et al. (2019) also suggest that the current build-up in external debt is due to a significant increase in private borrowing. They observe that the share of private lending to Africa has risen from 9 percent of external debt in 2000 to 17 percent in 2017. In addition, the debt portfolio of some of the African countries includes Eurobonds, accounting for a total of $\$ 17$ billion and in some cases term-to-maturity of 30-years.

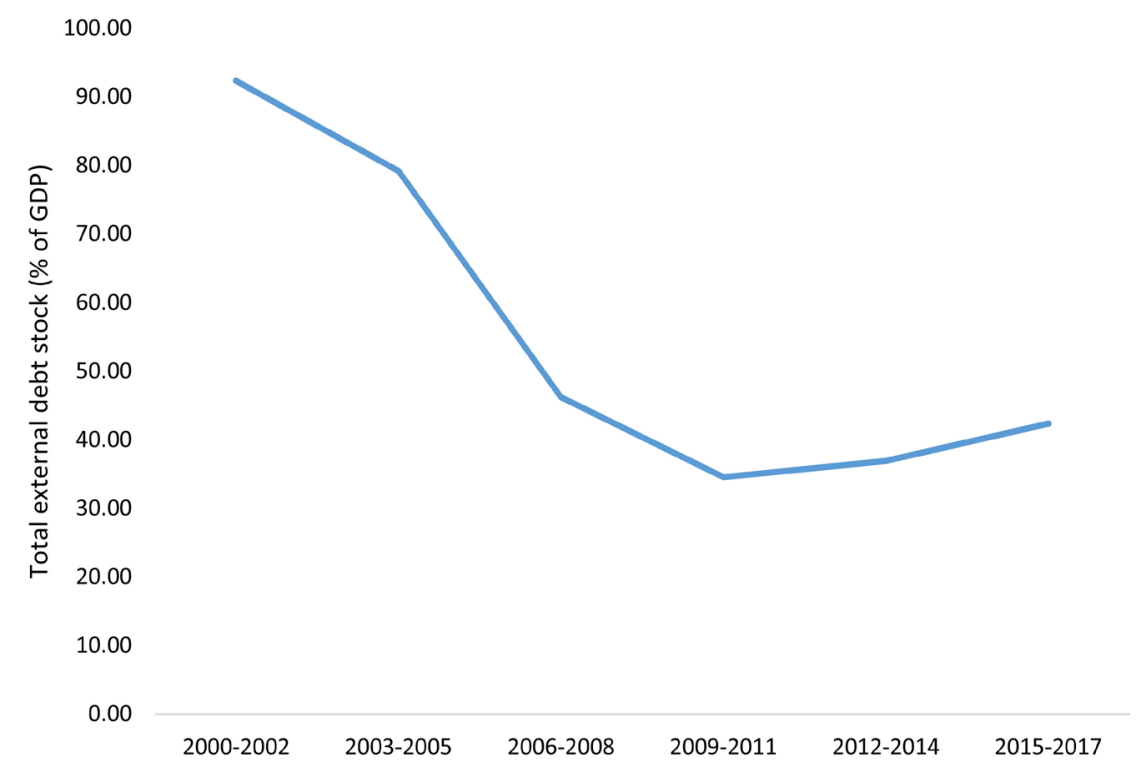

Figure 4. Africa's total external debt-to-GDP. Source: Authors' calculations based on data from World Bank. 
Table 2. Total external debt-to-GDP for African countries.

\begin{tabular}{|c|c|c|c|c|c|c|}
\hline & $2000-2002$ & 2003-2005 & 2006-2008 & 2009-2011 & $2012-2014$ & 2015-2017 \\
\hline Africa & 92.33 & 79.15 & 46.19 & 34.54 & 36.89 & 42.36 \\
\hline Algeria & 42.89 & 25.96 & 4.42 & 4.32 & 2.57 & 3.21 \\
\hline Angola & 75.78 & 41.90 & 18.22 & 20.56 & 18.20 & 29.84 \\
\hline Benin & 53.89 & 35.29 & 13.65 & 21.57 & 22.62 & 28.20 \\
\hline Botswana & 8.02 & 5.72 & 3.85 & 15.23 & 15.74 & 12.93 \\
\hline Burkina Faso & 52.03 & 39.30 & 19.98 & 22.72 & 21.50 & 25.43 \\
\hline Burundi & 134.49 & 145.16 & 99.33 & 30.60 & 26.22 & 19.37 \\
\hline Cabo Verde & 55.84 & 46.24 & 38.57 & 50.59 & 78.13 & 96.16 \\
\hline Cameroon & 96.82 & 61.15 & 14.04 & 11.71 & 15.26 & 26.08 \\
\hline Central African Rep. & 101.26 & 87.62 & 60.92 & 28.58 & 34.91 & 39.98 \\
\hline Chad & 61.01 & 35.68 & 20.71 & 19.85 & 22.78 & 29.57 \\
\hline Comoros & 110.90 & 82.48 & 62.06 & 49.90 & 28.47 & 24.66 \\
\hline Congo, Dem. Rep. & 106.52 & 109.62 & 73.28 & 41.24 & 18.23 & 13.11 \\
\hline Congo, Rep. & 161.24 & 136.08 & 69.97 & 30.37 & 24.35 & 48.73 \\
\hline Cote d'Ivoire & 103.73 & 75.41 & 66.96 & 52.74 & 31.62 & 34.08 \\
\hline Djibouti & 55.19 & 66.88 & 85.16 & 74.04 & 58.89 & 87.73 \\
\hline Egypt, Arab Rep. & 29.49 & 35.39 & 24.19 & 16.01 & 14.72 & 23.31 \\
\hline Eritrea & 59.48 & 70.98 & 69.43 & 48.74 & 27.42 & 16.55 \\
\hline Eswatini & 23.35 & 17.57 & 14.21 & 14.30 & 9.38 & 12.26 \\
\hline Ethiopia & 73.44 & 66.33 & 12.76 & 22.60 & 27.70 & 33.99 \\
\hline Gabon & 68.87 & 50.55 & 31.40 & 17.33 & 21.55 & 37.56 \\
\hline Gambia, The & 52.36 & 67.66 & 48.94 & 35.34 & 40.52 & 39.53 \\
\hline Ghana & 56.24 & 37.71 & 13.97 & 21.21 & 27.85 & 39.55 \\
\hline Guinea & 77.39 & 69.57 & 62.62 & 51.66 & 17.28 & 15.34 \\
\hline Guinea-Bissau & 245.62 & 202.28 & 153.38 & 98.28 & 26.82 & 26.46 \\
\hline Kenya & 40.87 & 36.39 & 23.60 & 23.20 & 25.42 & 31.88 \\
\hline Lesotho & 87.21 & 50.96 & 38.79 & 32.48 & 34.22 & 36.06 \\
\hline Liberia & 338.31 & 444.19 & 277.63 & 48.11 & 18.97 & 30.04 \\
\hline Madagascar & 105.86 & 82.86 & 28.78 & 31.28 & 28.55 & 30.10 \\
\hline Malawi & 86.73 & 94.46 & 20.03 & 16.11 & 26.11 & 31.80 \\
\hline Mali & 85.06 & 58.91 & 22.30 & 22.37 & 24.89 & 27.88 \\
\hline Mauritania & 177.98 & 128.37 & 51.15 & 59.56 & 63.34 & 82.85 \\
\hline Mauritius & 26.09 & 51.73 & 61.56 & 81.89 & 93.23 & 80.53 \\
\hline Morocco & 48.08 & 29.95 & 24.99 & 28.45 & 36.72 & 44.25 \\
\hline Mozambique & 89.35 & 65.22 & 32.01 & 37.24 & 48.46 & 87.86 \\
\hline Niger & 94.03 & 69.16 & 21.33 & 28.34 & 32.18 & 38.45 \\
\hline
\end{tabular}


Continued

\begin{tabular}{ccccccc}
\hline Nigeria & 41.50 & 27.15 & 4.31 & 4.61 & 4.13 & 8.08 \\
Rwanda & 79.79 & 74.24 & 14.71 & 16.81 & 21.06 & 31.88 \\
Sao Tome and Principe & 456.89 & 323.26 & 149.67 & 91.52 & 70.49 & 71.88 \\
Senegal & 60.65 & 41.42 & 17.05 & 23.69 & 27.81 & 36.79 \\
Sierra Leone & 120.42 & 113.53 & 43.97 & 35.58 & 30.66 & 41.63 \\
South Africa & 22.67 & 19.14 & 23.50 & 27.84 & 38.35 & 47.74 \\
Sudan & 102.29 & 66.68 & 35.17 & 34.79 & 41.00 & 39.48 \\
Tanzania & 54.34 & 52.24 & 22.46 & 28.44 & 28.88 & 33.13 \\
Tunisia & 59.45 & 61.41 & 51.56 & 50.90 & 55.66 & 70.08 \\
Uganda & 61.14 & 57.50 & 12.54 & 15.04 & 27.02 & 40.80 \\
Zambia & 157.24 & 108.99 & 18.71 & 22.66 & 26.76 & 64.18 \\
Zimbabwe & 34.48 & 49.86 & 72.94 & 56.28 & 44.93 & 43.50 \\
\hline
\end{tabular}

Source: Authors' calculations based on data from World Bank.

Table 3 shows that in comparison to the USA, Germany and United Kingdom, Africa holds lesser external debt. The Table shows that, development projects in the USA, Germany and United Kingdom are financed by external investors. The question here again is why are these investors prepared to hold more of the debts of these countries and are not complaining of debt distress in these countries. An assessment is needed to understand the risk structures in these countries compared to those in Africa.

Improved macroeconomic fundamentals in a number of African countries have also allowed them to access international financial markets. Adeniran et al. (2018) note that, access to these financial markets has allowed countries to diversify sources of funding while exposing their economies to the disciplines of the financial markets. It has to be said that access to the markets come with the risk of being exposed to some financial risks, including exposure to global market volatility and other developments outside the control of local policymakers. Hence, shocks to the markets have caused unforeseen volatilities to interest rates, exchange rates, and debt rollover risks for the countries.

In recent years, Africa is attracting creditors outside the traditional bilateral partners. Coulibaly et al. (2019) find that in 2017, Paris Club countries owned less than 7 percent of Africa's outstanding external debt, down from 15 percent in 2008, allowing the continent to diversify their external funding sources. China represents the new holders of Africa's debt. Most of the Chinese debts are used to support infrastructure developments in Africa. Coulibaly et al. (2019) indicate that China committed $\$ 125$ billion in loans to African countries between 2000 and 2017. Furthermore, they find that Chinese lending to the region has accelerated since 2012 to about $\$ 10$ billion every year from an average of $\$ 5$ billion between 2005 and 2010. Angola has been the largest recipient of Chinese loans, accounting for a third of Chinese lending in Africa. The other top destinations 
Table 3. Total external debt-to-GDP for selected countries.

\begin{tabular}{cccccc}
\hline & $2004-2006$ & $2007-2009$ & $2010-2012$ & $2013-2015$ & $2016-2018$ \\
\hline Brazil & 23.91 & 16.49 & 16.43 & 24.15 & 28.57 \\
China & 12.14 & 9.15 & 13.09 & 14.63 & 13.69 \\
India & 16.16 & 17.93 & 18.94 & 22.74 & 19.34 \\
Russia & 31.26 & 28.18 & 26.36 & 30.07 & 33.21 \\
South Africa & 19.36 & 25.08 & 31.17 & 40.65 & 49.14 \\
Africa & 67.72 & 41.01 & 34.25 & 37.78 & 47.67 \\
USA & 74.12 & 93.67 & 97.80 & 97.98 & 96.81 \\
Germany & 141.19 & 152.92 & 160.84 & 147.52 & 145.49 \\
UK & 293.51 & 344.01 & 368.65 & 308.70 & 301.90 \\
\hline
\end{tabular}

Source: Authors' calculations based on data from World Bank.

for Chinese loans are Ethiopia and Kenya. Despite the increase in Chinese lending to Africa, China is not a majority holder of external debt in most countries. Eom et al. (2018) indicate that China holds the majority of external debt of Republic of the Congo and Zambia, which are in or at risk of debt distress. Chinese lending in the two countries total around $\$ 14$ billion, representing just over a tenth of its total lending on the continent.

\section{Triggers of Debt Crisis}

This section pays attention to sovereign debts and discusses the origins of sovereign debt crises. This is particularly important because a deep understanding of the common causes of debt crises would help policymakers to take actions to avert future crises. Knowledge of the causes and solutions would also prevent emergence of "vulture funds," where specialized entities purchase distressed debt on the secondary market significantly below its face value, and then seek to recover the full amount, often through litigation.

Brooks et al. (1998) reveal that, exogenous shocks, such as adverse terms-of-trade, lack of sustained macroeconomic adjustment policies and structural reforms, to respond to shocks, lending and refinancing by creditors on unfavourable terms, lack of prudent debt management by borrowing countries, and political factors, including civil war and social strife as the key causes of debt crises.

Debt crises could be triggered when there is slow economic growth, therefore reducing the capacity of a country to mobilize enough resources to service its debts. Continuous rising interest rates (meaning rising cost of servicing debt), leading to a vicious cycle of larger and larger interest payments is also a recipe for debt crisis. However, there are other contributing factors responsible for debt crisis. These factors include imprudent lending and borrowing; structural vulnerabilities and exposure to shocks (e.g. natural disasters and commodity prices) and political instability ${ }^{4}$.

${ }^{4}$ This section is drawn from Mustapha and Prizzon (2015). 
The root cause of the debt crisis experienced by several developing countries in the 1980s and 1990 can be traced to windfall increases in income, particularly for petroleum exporting countries in the mid-1970s. Massive surplus capital accrued in the 1970s by OPEC countries in Western Banks as result of the rise in the price of oil made OECD countries to embarking on imprudent lending behaviours. The OECD used the excess capital to actively extend of loans to developing countries, often without careful credit analysis. African countries borrowed abroad to support their public expenditure programmes on the expectations of higher commodity prices in the future and therefore optimistic expectations of the repayment capacity of their debt. These assumptions turned out to materialize, resulting in the exposure of the vulnerability of debtor countries.

On the other hand, debt crisis could happen because of imprudent borrowing. Some countries borrow to support projects with limited or no economic returns or poorly planned projects, or were procured for projects that never took off or later became "white elephants". Furthermore, some countries take out loans to correct for balance of payments imbalances, without the implementation of appropriate sound fiscal and monetary policies needed to address the economic fundamentals.

Structural vulnerabilities of an economy and exposure to shocks could potentially place a country in debt crisis. The drop in the prices of primary commodities worldwide in the late 1970s and early 1980s triggered debt crisis for a number of African countries. This is because volatile commodity prices cause deteriorating terms-of-trade and consequently lower export earnings which in turn hinders the capacity of the country to repay its external debt. Vulnerability is often greater for smaller and emerging market countries because their economies tend to be less diversified, have a smaller base of domestic financial savings, less developed financial systems, and may be more susceptible to financial contagion through capital flows. However, events of the 2007/2008 global financial crisis have taught us that larger and developed economies have their own structural vulnerabilities in regards to exposure to external shocks.

Lastly, countries experiencing political instability, civil strife and weak institutions of governance are bound to face debt crisis. Conflicts have the potential of eroding the export base of a country by destroying its infrastructure and the economy. Political instability and conflicts also raise the level of debt-financed military imports, contributing to worsening the debt-to-GDP ratio of the country and reducing the capacity of repayments of debt. This is a manifestation of imprudent borrowing as the military expenditure generally does not contribute to boosting the productivity of countries in conflict ${ }^{5}$.

Brooks et al. (1998) propose a number of measures to reverse the triggers. First, strong and sustained sound macroeconomic and structural adjustment policies are needed to address the negative impact term-of-trade shocks so as to spur growth. Second, countries need to diversify their export base, with limited reli- 
ance on commodities that are subject to large price swings to commodity price shocks. Third, there is the need for prudent debt management strategies.

\section{An Arithmetic of Debt Sustainability}

In order to remind ourselves of the key variables influencing debt of a country, this section is inspired and drawn from Ley (2010). This section presents the conventional concept of debt sustainability. This concept indicates that the budget constraint faced by a government, at any point in time, suggests that a (primary) fiscal deficit not financed by money creation adds to the public debt. In other words, the debt at time $t$ is equal to the debt at time $t-1$ plus the interest paid on the debt less the creation of money and the primary budget balance (the difference between tax revenues and foreign aid in the form of grants, and recurrent government expenditures).

More formally, let $D_{t}$ be the stock of government debt at time $t$, let $i_{t}$ be the average nominal interest rate paid on the debt, $B_{t}$ the primary government balance, and let $M_{t}$ represent stock of high-powered money. Hence the government budget constraint is:

$$
D_{t}=\left(1+i_{t}\right) D_{t-1}-B_{t}-\Delta M_{t}
$$

If $T_{t}$ is the accrued tax revenue to the government, $A_{t}$ is grant/foreign aid and $G_{t}$ is government expenditure then the primary balance is:

$$
B_{t}=T_{t}+A_{t}-G_{t}
$$

Note that the government achieves primary surplus when $B_{t}>0$ and a primary deficit when $B_{t}<0$ while $\Delta M$ is seigniorage or monetary financing.

In assessing the ability of a government to sustain its debt load, one has to examine the changes in the debt indicators over time. This requires normalization of the indicators by a measure of the government's ability to service debt, such as government revenue, GDP and exports in the case of external debt. The most commonly used indicator in normalizing the debt is the GDP. So dividing Equation (1) by the nominal GDP, $P_{t} Y_{t}$ yields:

$$
\frac{D_{t}}{P_{t} Y_{t}}=\frac{\left(1+i_{t}\right) D_{t-1}}{P_{t} Y_{t}}-\frac{B_{t}}{P_{t} Y_{t}}-\frac{\Delta M_{t}}{P_{t} Y_{t}}
$$

where $P_{t} Y_{t}=\left(1+\pi_{t}\right) P_{t-1}\left(1+g_{t}\right) Y_{t-1}, \pi_{t}$ is the inflation rate and $g_{t}$ is the real growth rate. Based on this, Equation (2) can therefore be expressed as:

$$
\frac{D_{t}}{P_{t} Y_{t}}=\frac{1+i_{t}}{\left(1+g_{t}\right)\left(1+\pi_{t}\right)}\left(\frac{D_{t-1}}{P_{t-1} Y_{t-1}}\right)-\frac{B_{t}}{P_{t} Y_{t}}-\frac{\Delta M_{t}}{P_{t} Y_{t}}
$$

By expressing the ratios of the indicators to GDP in lowercase, Equation (3) becomes:

$$
d_{t}=\frac{1+i_{t}}{\left(1+g_{t}\right)\left(1+\pi_{t}\right)} d_{t-1}-\left(b_{t}+\Delta m_{t}\right)
$$

By expressing $\left(1+i_{t}\right)=\left(1+r_{t}\right)\left(1+\pi_{t}\right)$, where $r$ is the real interest rate, Equa- 
tion (4) also becomes:

$$
d_{t}=\frac{1+r_{t}}{1+g_{t}} d_{t-1}-\left(b_{t}+\Delta m_{t}\right)
$$

or

$$
d_{t}=\psi_{t} d_{t-1}-\left(b_{t}+\Delta m_{t}\right)
$$

where $\psi_{t}=\frac{1+r_{t}}{1+g_{t}}$ is a discount factor. As pointed by Ley (2010), Equation (6) is the fundamental fiscal-sustainability identity. For simplicity, we assume that seigniorage is zero or it has been included in the primary balance. Hence, solving Equation (6) iteratively will yield:

$$
d_{t}=d_{o} \prod_{i=1}^{t} \psi_{i}-\sum_{i=1}^{t} b_{i} \prod_{j=i+1}^{t} \psi_{j}
$$

Introducing further simplicity by assuming constant balances and discount factor, and by dropping the time subscript, Equation (7) becomes:

$$
d_{t}=d_{0} \psi^{t}-b \sum_{i=0}^{t-1} \psi^{i}
$$

Equation (8) is very important for a policymaker. From Equation (8), we can extract the primary balance plus seigniorage as:

$$
b=\frac{d_{0} \psi^{t}-d_{t}}{\sum_{i=0}^{t-1} \psi^{i}}
$$

Let us say a government now commits to fiscal targets that require that the debt-to-GDP ratio, $\bar{d}$, must be achieved by time $T$. Hence, Equation (9) becomes:

$$
b=\frac{d_{0} \psi^{T}-\bar{d}}{\sum_{i=0}^{T-1} \psi^{i}}
$$

If the growth rate of the economy is the same as the real interest rate, then $\psi=1$. In this case the primary balance plus seigniorage required to fill the gap each year as per Equation (9) will be:

$$
b=\left(d_{0}-\bar{d}\right) / T
$$

From Equation (6), it is clear that debt of the country is manageable if the economy grows at a higher rate than the real interest rate. In this case $\psi<1$ and the debt will be falling over time and the government will eventually finance its development projects from the primary balance and seigniorage.

However, what happens where $r_{t}>g_{t}$ or $\psi_{t}>1$ ? This presents a serious challenge for policy makers. In such a scenario the debt ratio will blow up unless primary surplus plus the seigniorage, $\left(b_{t}+\Delta m_{t}\right)$, is large enough to mitigate [see Equation (6)]. Using the assumptions underlying Equations (10) and (11) implies that:

$$
\frac{d_{0} \psi^{T}-\bar{d}}{\sum_{i=0}^{T-1} \psi^{i}}>\frac{d_{0}-\bar{d}}{T}>0
$$


The policy recommendation for governments is that when the economy is growing less than the real interest rate on the debt, then it has to run a very large primary surplus so that the debt-to-GDP ratio does not explode.

The next logical issue is how a policymaker stabilizes the debt-to-GDP ratio. To address this, let us begin with Equation (5) by subtracting $d_{t}$ from both sides and rearranging:

$$
\Delta d_{t}=\left(\frac{r_{t}-g_{t}}{1+g_{t}}\right) d_{t-1}-b_{t}
$$

The implications of Equation (13) is that, if the average interest rate is structurally higher than the growth rate of the economy then the debt-to-GDP ratio will explode unless the government maintains a large primary balance and seigniorage. Keeping the debt-to-GDP ratio stable also will require a primary balance and seigniorage. On the other hand, when the growth rate of GDP exceeds the average rate of interest on public debt, keeping the debt-to-GDP ratio stable or even reducing it is compatible with running a primary balance and seigniorage deficit. The intuition for this result is that higher growth will generate higher revenues that will make it easier to pay the government debt in the future.

\section{Stabilizing the Debt-To-GDP Ratio}

Stabilization of the debt-to-GDP ratio requires that there is no change in the ratio or $\Delta d_{t}=0$. This implies that the debt-stabilizing primary balance-cumseigniorage will be:

$$
b_{t}^{*}=\left(\frac{r_{t}-g_{t}}{1+g_{t}}\right) d_{t-1}
$$

where $b_{t}^{*}$ is the required primary balance-cum-seigniorage to stabilize the public debt-to-GDP ratio. It is imperative to note that, countries that are able to borrow at concessional interest rates, the likelihood of realizing a positive growth-to-interest rate differential is very high. Hence, countries borrowing at concessional interest rate potentially could achieve debt sustainability even when running fiscal primary deficits.

\section{Sustainable Fiscal Policy and Solvency}

It is imperative to note that, in analysing the fiscal stance of a government, one has to analyze its debt and primary balance over a period of time. This is particularly necessary as governments generally shift spending between periods to meet annual fiscal targets. Hence, to understand the sustainability of fiscal policy over time, we assess the government's financing constraint in a dynamic intertemporal manner in order to ensure solvency. Such analysis allows a government that currently faces substantial fiscal deficits and a high (or possibly) unsustainable debt-to-GDP ratio can be solvent as long as resources generated in the future are sufficiently large enough to cover all future debt-service obliga- 
tions.

The solvency of the debt depends on present value of stream of primary balance plus seigniorage matched against the present value of debt payments. So let $P_{t}$ be the future principal and interest of the debt in period $t$. By using the average nominal interest rate of the debt to discount the future stream of payments on the debt, we have the present debt as:

$$
P V D(P, r, \pi)=\sum_{t=s}^{\infty} \frac{P_{t}}{[(1+\pi)(1+r)]^{t-s}}
$$

In the same vein, if the future stream of primary balance in period is $B_{t}$, then the present value of the primary balance is:

$$
\operatorname{PVB}(B, r, \pi)=\sum_{t=s}^{\infty} \frac{B_{t}}{[(1+\pi)(1+r)]^{t-s}}
$$

Solvency therefore requires that, the present value of the primary balance should be greater or equal to the present value of the debt:

$$
\sum_{t=s}^{\infty} \frac{B_{t}}{[(1+\pi)(1+r)]^{t-s}} \geq \sum_{t=s}^{\infty} \frac{P_{t}}{[(1+\pi)(1+r)]^{t-s}}
$$

It is crucial to note that, the government is considered solvent as long as Equation (17) holds. As explained by Cassimon et al. (2008), the case of an equality between debt-service obligations and future primary fiscal balances is referred to as the "no-Ponzi game" condition. What Equation (17) tells us is that, there is no unique fiscal stance that ensures solvency. This is because solvency is intertemporal and therefore current higher expenses could be addressed by a cut in future spending. Governments therefore have the flexibility to adopt different fiscal policy packages.

This framework can be used to calculate the required primary surplus necessary to stabilize the debt-to-output ratio. Following Ley (2010), we assume that the primary balances evolve over time in line with nominal GDP growth, $B_{t}=(1+g)(1+\pi) B$, so that the balance as a percent of GDP is constant such that $b_{t}=\frac{B}{Y_{s}}=b$. Plugging into Equation (16) yields:

$$
\begin{aligned}
P V D(P, r, \pi) & =\frac{B}{Y_{s}} \sum_{t=s}^{\infty}\left[\frac{(1+\pi)(1+g)}{(1+\pi)(1+r)}\right]^{t-s} \\
& =\frac{1+g}{1+r} b \sum_{t=s}^{\infty}\left[\frac{1+g}{1+r}\right]^{t-s}=\left(\frac{1+g}{r-g}\right) b
\end{aligned}
$$

To the extent that the current present value of debt is $d_{s}$ and the solvency condition requires that it is equal to the present value of primary balance in Equation (18), solving for $b$ becomes:

$$
\hat{b}=\left(\frac{r-g}{1+g}\right) d_{s}
$$


Equation (19) is similar to Equation (14), which determines the required balance to sustain a stable debt-to-GDP ratio, $b^{*}$. Notice that the constant primary surplus required for solvency does not need to bring the debt ratio to zero. What is very important is for primary surplus to stabilize the debt ratio.

\section{Adding External Debt}

We turn to consider external debt since a large portion of the debt portfolio is made-up of foreign-currency-denominated bonds. In this case, the inflation rate will be determined by domestic inflation for the non-tradeable sector, world inflation and exchange rate for the tradable sector. Hence, the total debt can be given as:

$$
D=D^{h}+e D^{f}
$$

where $D^{h}$, home or domestic denominated debt, $D^{f}$ is the external debt dominated in foreign currency and $e$ is the exchange rate in domestic currency per unit of foreign currency. Now let $f$-superscript denote foreign-denominated variables and $h$-superscript to denote (home) domestically-denominated variables.

Recalling Equation (1), the government budget constraint with external debt will now be:

$$
D_{t}=\left(1+i_{t}^{h}\right) D_{t-1}^{h}+\left(1+i_{t}^{f}\right) e_{t} D_{t-1}^{f}-\left(B_{t}+\Delta M_{t}\right)
$$

where $i_{t}^{h}$ is the effective nominal interest rate on domestic debt. Let the rate of change of the exchange rate be:

$$
\epsilon_{t}=\frac{e_{t}-e_{t-1}}{e_{t-1}}=\frac{\Delta e_{t}}{e_{t-1}}
$$

Note that $\epsilon_{t}>0$ implies depreciation of the local currency. Substituting $e_{t}=\left(1+\epsilon_{t}\right) e_{t-1}$ into Equation (21) yields:

$$
D_{t}=\left(1+i_{t}^{h}\right) D_{t-1}^{h}+\left(1+\epsilon_{t}\right)\left(1+i_{t}^{f}\right) e_{t-1} D_{t-1}^{f}-\left(B_{t}+\Delta M_{t}\right)
$$

Next, let $\propto^{f}$ be the portion of foreign-denominated government debt. Thus $\propto^{f}=e_{t-1}\left(\frac{D_{t-1}^{f}}{D_{t-1}}\right)$ and $\propto^{h}=\left(1-\propto^{f}\right)$, the portion of foreign-denominated debt. The debt-dynamics of Equation (23) now becomes:

$$
D_{t}=\left[\propto^{h}\left(1+i_{t}^{h}\right)+\propto^{f}\left(1+\epsilon_{t}\right)\left(1+i_{t}^{f}\right)\right] D_{t-1}-\left(B_{t}+\Delta M_{t}\right)
$$

Further simplification of Equation (24) produces Equation (25) below:

$$
D_{t}=\left[1+\propto^{h} i_{t}^{h}+\propto^{f}\left(i_{t}^{f}+\epsilon_{t}+i_{t}^{f} \epsilon_{t}\right)\right] D_{t-1}-\left(B_{t}+\Delta M_{t}\right)
$$

Equation (25) implies that the effective nominal interest rate, $i_{t}$, is a weighted average of domestic rates and a term involving foreign rates and exchange-rate movements:

$$
i_{t}=\propto^{h} i_{t}^{h}+\propto^{f}\left(i_{t}^{f}+\epsilon_{t}+i_{t}^{f} \epsilon_{t}\right)
$$


Rearranging further:

$$
\begin{gathered}
i_{t}=\propto^{h} i_{t}^{h}+\propto^{f} i_{t}^{f}+\propto^{f} \in_{t}\left(1+i_{t}^{f}\right) \\
i_{t}=\hat{i}_{t}+\propto^{f} \in_{t}\left(1+i_{t}^{f}\right)
\end{gathered}
$$

where $\hat{i}_{t}=\propto^{h} i_{t}^{h}+\propto^{f} i_{t}^{f}$. It is important to note that the exchange rate may affect the debt burden. Equation (27) shows that the effective interest rate is made-up of: (i) a weighted average of domestic and foreign interest; and (ii) the exchange-rate induced valuation gains or losses in the foreign-debt obligations. The policymaker therefore needs to manage the exchange rate carefully as the exchange-rate induced valuation gains or losses in the foreign-debt obligations may grow substantially during an exchange-rate crisis.

Before going any further, a digression is made to derive an expression for the domestic inflation dynamics in an open economy. Inspired by Ley (2010), let the superscripts $f$ and $h$ represent the tradable and non-tradable sectors, respectively. In this case, the nominal GDP can be expressed as:

$$
P Y=P^{h} Y^{h}+e P^{f} Y^{f}
$$

Furthermore, let $\beta^{h}=P_{t-1}^{h} Y_{t-1}^{h} / P_{t-1} Y_{t-1}$ be the share of the non-tradable sector while that of the tradable sector becomes $\beta^{f}=1-\beta^{h}$. Ley (2010) demonstrates that:

$$
\begin{gathered}
P_{t} Y_{t} \approx\left(1+g_{t}\right)\left(1+\pi_{t}\right) P_{t-1} Y_{t-1} \\
g_{t}=\beta^{h} g_{t}^{h}+\beta^{f} g_{t}^{f} \\
\pi_{t}=\beta^{h} \pi_{t}^{h}+\beta^{f}\left(\pi_{t}^{f}+\epsilon_{t}+\epsilon_{t} \pi_{t}^{f}\right) \\
\pi_{t}=\hat{\pi}_{t}+\beta^{f} \in_{t}\left(1+\pi_{t}^{f}\right)
\end{gathered}
$$

where $\hat{\pi}_{t}=\beta^{h} \pi_{t}^{h}+\beta^{f} \pi_{t}^{f}$ is a weighted average of domestic and foreign inflation rates. Just like the nominal interest rate [see Equation (28)], in an open economy, the inflation rate is composed of: 1) a weighted average of domestic and foreign inflation rates, and 2) the exchange-rate induced valuation gains or losses in the tradable-sector output. It has to be noted that for simplicity, the analysis assumes that the tradable and non-tradable sectors grow at the same rate which may not entirely be the case.

We follow the law of motion of the government debt-to-GDP ratio [see Equation (5)] using the growth rate [Equation (31)], the effective nominal interest rate [Equation (28)] and inflation rate [Equation (33)] for the open economy. Hence substituting Equations (28) and (33) into Equation (5), the dynamics of debt is of the form:

$$
d_{t}=\left[\frac{1+\hat{i}_{t}+\propto^{f} \epsilon_{t}\left(1+i_{t}^{f}\right)}{\left(1+g_{t}\right)\left(1+\hat{\pi}_{t}+\beta^{f} \in_{t}\left(1+\pi_{t}^{f}\right)\right)}\right] d_{t-1}-\left(b_{t}+\Delta m_{t}\right)
$$

and therefore 


$$
\Delta d_{t}=\left[\frac{1+\hat{i}_{t}+\propto^{f} \in_{t}\left(1+i_{t}^{f}\right)}{\left(1+g_{t}\right)\left(1+\hat{\pi}_{t}+\beta^{f} \in_{t}\left(1+\pi_{t}^{f}\right)\right)}-1\right] d_{t-1}-\left(b_{t}+\Delta m_{t}\right)
$$

Now define $\rho$ as the real interest rate in an open economy such that:

$$
1+\rho_{t}=\frac{1+\hat{i}_{t}+\propto^{f} \in_{t}\left(1+i_{t}^{f}\right)}{1+\hat{\pi}_{t}+\beta^{f} \in_{t}\left(1+\pi_{t}^{f}\right)}
$$

and therefore

$$
\rho_{t}=\frac{\left(\hat{i}_{t}-\hat{\pi}_{t}\right)+\epsilon_{t}\left[\propto^{f}\left(1+i_{t}^{f}\right)-\beta^{f}\left(1+\pi_{t}^{f}\right)\right]}{1+\hat{\pi}_{t}+\beta^{f} \epsilon_{t}\left(1+\pi_{t}^{f}\right)}
$$

substituting into Equation (34) yields:

$$
\Delta d_{t}=\left(\frac{\rho_{t}-g_{t}}{1+g_{t}}\right) d_{t-1}-b_{t}
$$

Equation (35) is very similar to Equation (13) where the primary surplus includes the seigniorage.

Intuitively, Calvo et al. (2003) suggest that the exchange rate shocks affect the economy in three ways via its: 1) effect on the domestic cost of servicing interest of foreign-denominated debt; 2) effect on the value in domestic currency of the foreign-denominated debt; and 3) effect on the value of GDP in domestic currency through changes in prices in the tradable sector. Furthermore, Equation (34) shows that, since the debt ratio involves foreign-denominated variables both in the numerator and denominator, shocks to the exchange rate have effects on the debt ratio.

\section{External Debt Sustainability}

A major concern of most developing countries is how to sustain their external debt based on the receipts of their foreign exchange. This means that the policymaker needs to assess the sustainability of the combined public and private debts from a foreign exchange or external point of view. In other words, the policymaker needs to gauge sustainability in terms of a foreign exchange as a constraint rather than a fiscal constraint, which is what we have been considering so far. Parker and Kastner (1993) point that, sustainable fiscal stance achieved when private sector investment exceeds private sector savings may not necessarily be sufficient for external sustainability. On the other hand, when the balance of private savings less private investment is positive and mitigates against an unsustainable fiscal deficit, then potentially an unsustainable fiscal deficit may translate into a sustainable external position. Potentially, an economy may experience divergence between fiscal and external sustainability from time to time.

In conducting the external debt analysis, all variables (including output) are expressed in US dollars rather than domestic currency. The analysis is very sim- 
ilar to the analysis on fiscal sustainability. So let $D_{t}^{f}$ [Equation (20)] be the stock of all (public and private) external debt expressed in US dollars. The law of motion of the debt stock, as per Equation (1), is now the country's budget constraint in relation to the rest of the world expressed as:

$$
D_{t}^{f}=\left(1+i_{t}^{f}\right) D_{t-1}^{f}-\left(C A_{t}+T R_{t}\right)-F I_{t}+\Delta N F A_{t}
$$

where $i_{t}^{f}$ is the average nominal interest rate on total foreign debt; $C A_{t}$ is the non-interest current account, except for current transfers; $T R_{t}$ is the sum of official grants and other current transfers; $F I_{t}$ is the non-debt-creating (that is, equity) capital flows; and $\triangle N F A_{t}$ is the change in official reserves and other foreign assets (with a positive figure denoting an increase in foreign assets). By expressing output in US dollars, Equation (29) then becomes:

$$
\frac{P Y}{e}=\frac{P^{h} Y^{h}}{e}+P^{f} Y^{f}
$$

as before, we define $\beta^{h}$ as the share of the non-tradable sector and $\beta^{f}$ as the share of the tradable sector. The sustainable debt-to-GDP ratio equation analogous to Equations (13) and (34) is:

$$
\Delta d_{t}=\left[\frac{1+\hat{i}_{t}+\propto^{h} \xi_{t}\left(1+i_{t}^{h}\right)}{\left(1+g_{t}\right)\left(1+\hat{\pi}_{t}+\beta^{h} \xi_{t}\left(1+\pi_{t}^{h}\right)\right)}-1\right] d_{t-1}-c a_{t}
$$

where $\xi_{t}$ is the rate of change of the inverse of the exchange rate, $(1 / e), \propto^{h}$ is the portion of domestic debt in total debt and $c a_{t}$ is current account to GDP ratio inclusive of official grants and other current transfers, non-debt-creating capital flows and the change in official reserves and other foreign assets. Equation (38) shows that the current-account balance is crucial in achieving external debt sustainability.

Finally define $\rho_{t}^{f}$ as the real interest on the external debt as:

$$
\begin{gathered}
1+\rho_{t}^{f}=\frac{1+\hat{i}_{t}+\propto^{h} \xi_{t}\left(1+i_{t}^{h}\right)}{1+\hat{\pi}_{t}+\beta^{h} \xi_{t}\left(1+\pi_{t}^{h}\right)} \\
\rho_{t}^{f}=\frac{\left(\hat{i}_{t}-\hat{\pi}_{t}\right)+\xi_{t}\left(\propto^{h}\left(1+i_{t}^{h}\right)+\beta^{h}\left(1+\pi_{t}^{h}\right)\right)}{1+\hat{\pi}_{t}+\beta^{h} \xi_{t}\left(1+\pi_{t}^{h}\right)}
\end{gathered}
$$

Substituting the above expression into Equation (38), we analogously express Equations (5) and (35) as:

$$
\Delta d_{t}=\left(\frac{\rho_{t}^{f}-g_{t}}{1+g_{t}}\right) d_{t-1}-c a_{t}
$$

Similarities between Equation (39) and Equation (5) or Equation (35) are that the debt-to-GDP ratio is influenced by the difference between the real interest rate on the debt and the real growth rate of GDP. However, it is imperative to note that the variables in Equation (39) are in dollar terms while those in Equations (5) and (35) are in domestic currency. Secondly, Cassimon et al. (2008) 
observe that the non-interest current account not financed by non-debt-creating equity flows or changes in the foreign reserves position feeds into higher external debt, whereas non-interest current account surpluses can reduce the external debt stock. What this means is that, should the average interest rate be structurally higher than the growth rate of GDP, then the debt-to-GDP ratio will rise unless the country runs a sufficiently large non-interest current account surplus. On the other hand, if the growth rate of GDP exceeds the average rate of interest on external debt, keeping the debt-to-GDP ratio stable, or even reducing it, is compatible with running a current account deficit.

The exchange rate also impacts on the dynamics of the external debt-to-GDP ratio. A depreciation of the exchange rate increases the ratio of external debt to GDP as it decreases the dollar value of GDP. However, the impact of the exchange rate depends on the shares of tradable versus non-tradable output. The impact will be higher if the share of tradable output is lower, with the maximum impact occurring when tradable output is zero.

\section{Debt Management: The Way Forward}

In order to address the challenges of debt, it is of utmost importance for a country to embark on prudent debt management. This will require that the country establishes and implements a strategy for the management of its debt in order to raise the required amount of funding at the lowest possible cost over the medium to long run, consistent with a prudent degree of risk ${ }^{6}$. The country also needs to meet any other public debt management goals it has, such as developing and maintaining an efficient market for government securities or debt to GDP ratio. Furthermore, in terms of scope, debt management should encompass the main financial obligations over which the central government exercises control.

Furthermore, it is important for countries to ensure that, both the level and rate of growth of their public debt are on a sustainable path and that the debt can be serviced under wide range of circumstances while meeting cost and risk objectives. Public debt managers need to monitor any emerging debt sustainability problems, based on portfolio risk analyses and market reactions observed when conducting debt management operations, and inform the government on a timely basis.

There are benefits to be gained from good public debt management. First, it can help countries reduce their borrowing cost. Countries with a well-designed and implemented borrowing programme give confidence to investors and thus reduce the lending spread. Second, a carefully balanced composition of securities can help the country to manage risk better and contribute to the development of the domestic financial market. Domestic financial institutions benefit from having available public debt instruments in which to invest and which can provide benchmarks for the pricing of other instruments. It has to be noted that, a well-developed domestic financial market can facilitate economic growth (Ibra${ }^{6}$ See IMF (2014). 
him \& Alagidede, 2018a, 2018b), and make the economy more resilient to external shocks (Ibrahim \& Alagidede, 2017). Third, effective debt management practices can reduce the vulnerability of the economy to economic and financial shocks. Poorly structured debt portfolios, in terms of maturity, currency, or interest rate composition and large contingent liabilities, contribute to propagating economic crises and consequently trigger debt crisis for a country.

As African countries embark on strategies to achieve its development objectives, it is essential that they continue to take measures that ensure debt sustainability. This is will require fiscal consolidation, coupled with diversification of the economy. This consolidation may also require fiscal adjustment through steady increases in tax revenues over the next few years. Reaching this level will require broadening the tax base, restructuring tax structures, streamlining exemptions, and strengthening the administration of taxes. Efforts are also needed to account for off-balance-sheet risks, improve debt-management capacity, and enhance data coverage of debt and debt exposure. Lastly, Governments must improve prospects for private investment. Faced with growing public debt vulnerabilities, African countries must continue on shifting from public to private investment by strengthening regulatory and insolvency frameworks, strengthening the financial sector and deepening access to credit.

Part of the prudent management of debt is achieving debt sustainability. Sustainability requires that governments take actions to influence fiscal balances, flow of foreign exchange, trade balances and current accounts. In this balancing act, care needs to be taken by policymakers to ensure that there is no conflict between the servicing of the debt service and growth and/or poverty reduction. In other words, policymakers should prevent a situation where debt itself does not constrain growth and poverty alleviation efforts.

Sustainability of the debt also requires that a country avoids debt overhang, which Krugman (1988) defines as the negative effect of a large debt burden on economic growth. Cassimon et al. (2008) indicate that debt overhang occurs when an excessive debt stock impacts negatively on the economy beyond the transfer of resources, by first affecting investment and then on economic growth. The impact is just like the "Ricardian equivalence" in the sense that high (current and future) debt transfers lead to anticipation by domestic and foreign investors of future higher taxes and increased uncertainty, both of which create a disincentive effect on the present investment or adjustment decisions of an indebted country. Here, investment is defined broadly as the accumulation in human capital stock through spending on education and health care as well as in physical capital, such as machinery and infrastructure. Debt overhang could potentially reduce the willingness of debtor governments to implement adjustment programmes because of the possibility that large part of the returns will go to foreign creditors as increased debt-service transfers and will not stay in the country as increased consumption or additional investment capacity.

Krugman (1988) suggests that debt overhang gives rise to the concept of a 
debt Laffer curve. This is because expected payments to creditors could potentially decrease with higher debt at high debt ratios because of this debt overhang effect. This implies that for countries with high levels of debt, it might be in creditors' self-interest to grant some debt relief because it would lead to higher expected payments. Claessens (1990) and Cohen (1991) have empirically used information from the secondary market of value-impaired debt to empirically validate the existence of the debt Laffer curve. They also find some countries at the "wrong side" of the Laffer curve, where creditors collectively could benefit from granting debt relief.

Overall, policymakers need to have sound debt management frameworks and strategies that take into account their socioeconomic objectives as well as the necessary steps to strengthen governance around tax revenue collection. There is a need to recognize that each country's capacity to manage its debt is unique and differ from country to country. Country needs are determined by the constraints they face in capital markets, including the exchange rate regime, the quality of their macroeconomic and regulatory policies, the institutional capacity to design and implement reforms, and the country's credit standing, among others.

\section{Policy Recommendations and Conclusion}

This paper assesses Africa's debt and finds that its debt-to-GDP is rising and approaching levels that could potentially cause distress and reverse economic gains registered over the period. However, we observe that the debt-to-GDP ratio for Africa on average are comparable to other developing countries and well below that of advanced economies. This notwithstanding, the debt levels and debt-servicing costs in recent years appear very worrisome for African policymakers. Despite these concerns, the paper argues that we are not at the tipping point for another debt crisis. The analysis in the paper indicates that the structure of the portfolio of the African debt has changed, with the external foreign-currency debt accounting for about 60 percent of total debt. Given the absence of sound hedging mechanisms imply that, the high share of foreign-currency debt exposes countries to the volatilities of the global markets, particularly currency and interest rate risks.

The paper finds that African countries now have access to the financial markets and are able to issue Eurobonds on commercial terms. On one hand, the entry into the financial markets imposes discipline and accountability on policymakers as the markets scrutinize the economic fundamentals of the countries and their policies. On the other hand, the relatively short maturity of the commercial debt and higher interest rates make such instrument not very suitable to finance development projects with long-term gestation periods. It has to be noted that the oversubscriptions and favourable terms of Africa's sovereign bonds in the global financial markets show that the continent has gained the confidence of international investors thus providing countries some borrowing space.

The paper also argues that in addition to sound monetary and fiscal policies, 
countries should embark on debt management strategies that are growth-enhancing. However, the interest rate-growth differential is subject to shocks. While Africa's growth prospects are promising, the real interest could be rising in the future due to slower growth in emerging markets and tighter global financial conditions. The interest rate-growth differential being the main drivers of the overall debt dynamics indicates that African countries should aim at high growth as a key element of their debt sustainability strategy.

Overall, the paper recommends that policymakers could reduce debt-to-GDP ratio through accelerating growth and improving primary balances. In addition, policymakers may consider the following actions to prevent another debt crisis similar the HIPC/MDRI period. First, African countries need to continue strengthening the management of macroeconomic stability. A stable macroeconomic environment is a necessary ingredient for enhancing economic transformation process and growth. African governments should therefore strive to maintain macroeconomic stability. African governments should also aim at sustained economic growth and improved living standards of its citizens by establishing a stable economic environment for entrepreneurs. Indeed, in such stable economic environment comprising careful inflation management and public finance stability, entrepreneurs would expect to face a steady rise in demand and stable production costs. Consequently, they would be able to plan their production, marketing and investment strategies, which would translate in the development of the production sectors of local goods. Such a stable enabling and macroeconomic environment which spurs growth would help to reduce the debt burden of countries.

Second, countries need to intensify their mobilization of domestic resources with the view of reducing debt dependency. At the moment, the saving rate of African countries is around 15 percent of GDP, which is very low compared to other regions of the world. However, investment financing needs stand between 25 to 30 percent of GDP. Third, Africa needs to work collectively to minimize the Illicit Financial Flows (IFFs). UNECA (2015) suggests that, Africa loses between $\$ 50$ and $\$ 60$ billion per year through IFFs. Domestic governance failures, corruption and the practices of some multinational corporations to embark on tax avoidance and profit shifting are some of the channels through which the IFFs occur. Effectively combating IFFs would require policies at home as well as global cooperation on the taxation of multinational corporations. Furthermore, enforcement on taxation and better governance in natural resources would mobilize substantial resources to finance Africa's developmental needs. Fourth, African countries need to double-up its efforts to account for off-balance-sheet risks, improve debt-management capacity, and enhance data coverage of debt and debt exposure. Countries therefore need to embark on better strategies for the management of their debt so as to borrow at lowest possible cost. Fifth, African countries need to design and implement appropriate policies to increase private investment as large public debt chocks-off private investment. However, 
giving the growing public debt vulnerabilities, it is important that efforts are made for the private sector take up some of the public expenditures. The transition from public to private investment can be achieved through the strengthening of regulatory frameworks, access to credit and enhanced private-publicpartnership arrangements.

At the moment, foreign financial flows, through sovereign bonds to Africa are higher than those to emerging markets, coming from a broader range of sources, including frontier economies and China. This trend may not continue as capital flows are very fickle and therefore if Africa is to continue to take full advantage of the current mood of global integration of products, policymakers need to tackle public debt vulnerabilities aggressively. Not addressing the rising debt levels will only constrain the continent's potential to achieve sustainable and inclusive growth.

Given the discussions above, we proffer a key area for future research. Indeed, to the extent the overall growth effects of debt is ambiguous, it would be interesting to empirically examine how the interest rate-growth differential matter in debt-growth nexus. This is because the relative speed of interest rate and that of growth rate could serve as regime-switching triggers bifurcating the impact of debt on economic growth. In doing this, threshold models come in handy where the gap between interest and growth rates is used as the threshold variable mediating how debt influences growth and at what optimal level of the differential does debt sands or greases the wheel of economic growth.

\section{Acknowledgements}

The authors would like to thank colleagues at the UN Economic Commission for Africa, particular Adam Elhiraika, Christine Achieng Awiti and Adrian Guacci for the countless discussions. This paper has also benefitted immensely from the comments of Kwabena Duffour, Mahamudu Bawumia, J. Atsu Amegashie, as well as Ernest Addison, Maxwell Opoku-Afari, Philip Abradu-Otoo Ben Amoah, Steve Opata and others of the Bank of Ghana. However, the views contained in this paper should not be attributed to any of the aforementioned individuals, UN and the Government of Ghana. Authors take full responsibility for omissions and errors contained in the paper.

\section{Conflicts of Interest}

The authors declare no conflicts of interest regarding the publication of this paper.

\section{References}

Adeniran, A., Ekeruche, M., Bodunrin, S., Ali, A., Mandri, B., \& Ghazi, T. (2018). Africa's Rising Debt: Implications for Development Financing and Sustainable Debt Management Approach. Global Economic Governance Discussion Paper.

African Development Bank (AfDB) (2018). Africa's Infrastructure: Great Potential but 
Little Impact on Inclusive Growth. Abidjan, Côte d'Ivoire: African Economic Outlook.

Agénor, P. R. (2011). "Fiscal Policy, Public Debt Sustainability, and Solvency" (Lecture Notes). World Bank.

http://www1.worldbank.org/wbiep/macro-program/agenor/agenor lectures.htm

Agénor, P. R. (2012). Public Capital, Growth and Welfare: Analytical Foundations for Public Policy. Princeton, NJ: Princeton University Press.

https://doi.org/10.1515/9781400845392

Atta-Mensah, J. (2015). Towards Economic Transformation of Africa. China-USA Business Review, 14, 171-184. https://doi.org/10.17265/1537-1514/2015.04.001

Atta-Mensah, J. (2017). Theoretical Foundations of Africa's Economic Transformation and Growth. Theoretical Economics Letters, 7, 1150-1178.

https://doi.org/10.4236/tel.2017.75078

Blanchard, O. (2019). Public Debt and Low Interest Rates. America Economic Association Presidential Lecture, America Economic Review.

https://doi.org/10.3386/w25621

Brooks, R., Cortes, M., Fornasari, F., Ketchekmen, B., \& Metzgen, Y. (1998). External Debt Histories of Ten Low-Income Developing Countries-Lessons from Their Experience. IMF Working Paper 98/72. Washington DC: International Monetary Fund. http://www.imf.org/external/pubs/ft/wp/wp9872.pdf https://doi.org/10.5089/9781451849318.001

Calvo, G., Izquierdo, A., \& Talvi, E. (2003). Sudden Stops, the Real Exchange Rate and Fiscal Sustainability: Argentina’s Lessons. NBER Working Paper No. W9828.

http://papers.nber.org/papers/W9828

https://doi.org/10.3386/w9828

Cassimon, D., Moreno-Dodson, B., \& Wodon, Q. (2008). Debt Sustainability for Low-Income Countries: A Review of Standard and Alternative Concepts. Munich Personal RePEc Archive. https://mpra.ub.uni-muenchen.de/11077/

Claessens, S. (1990). The Debt Laffer Curve: Some Estimates. World Development, 18, 1671-1677. https://doi.org/10.1016/0305-750X(90)90062-3

Cohen, D. (1991). How to Evaluate the Solvency of an Indebted Nation. Economic Policy, 1, 139-167. https://doi.org/10.2307/1344614

Coulibaly, B., \& Gandhi, D. (2018). Mobilization of Tax Revenues in Africa: State of Play and Policy Options. Washington DC: Brookings Institution.

Coulibaly, B., Gandhi, D., \& Senbet, L. (2019). Is Sub-Saharan Africa Facing Another Systemic Sovereign Debt Crisis? Africa Growth Initiative Policy Brief, Washington DC: Brookings Institutions.

DeLong, B., \& Summers, L. (2012). Fiscal Policy in a Depressed Economy. Brookings Papers on Economic Activity. https://doi.org/10.1353/eca.2012.0000

Eom, J., Brautigam, D., \& Benabdallah, L. (2018). The Path Ahead: The 7th Forum on China-Africa Cooperation. Washington DC: China Africa Research Initiative, School of Advanced International Studies.

Greene, J. (1989). The External Debt Problem of Sub-Saharan Africa. IMF Economic Review, 36, 836-874. https://doi.org/10.2307/3867242

Greene, J., \& Khan, M. (1990). The African Debt Crisis. AERC (African Economic Research Consortium) Special Paper, No. 3.

Ibrahim, M., \& Alagidede, P. (2017). Financial Sector Development, Economic Volatility and Shocks in sub-Saharan Africa. Physica A, 484, 66-81. 
https://doi.org/10.1016/j.physa.2017.04.142

Ibrahim, M., \& Alagidede, P. (2018a). Effect of Financial Development on Economic Growth in Sub-Saharan Africa. Journal of Policy Modeling, 40, 1104-1125. https://doi.org/10.1016/j.jpolmod.2018.08.001

Ibrahim, M., \& Alagidede, P. (2018b). Nonlinearities in Financial Development and Economic Growth Nexus: Evidence from Sub-Saharan Africa. Research in International Business and Finance, 46, 95-104. https://doi.org/10.1016/j.ribaf.2017.11.001

International Monetary Fund (IMF) (2014). Revised Guidelines for Public Debt Management. IMF Policy Paper. https://www.imf.org/external/np/pp/eng/2014/040114.pdf https://doi.org/10.5089/9781498343602.007

International Monetary Fund (IMF) (2018). World Economic Outlook.

Jauch, H. (1999). Structural Adjustment Programmes: Their Origin and International Experiences. Labour Resource and Research Institute.

Kremer, M., \& Jayachandran, S. (2002). Odious Debt. Policy Brief 103, Washington DC: Brookings Institution. https://doi.org/10.3386/w8953

Krugman, P. (1988). Financing versus Forgiving a Debt Overhang. Journal of Development Economics, 29, 253-268. https://doi.org/10.1016/0304-3878(88)90044-2

Krumm, K. (1985). The External Debt of Sub-Saharan Africa: Origins, Magnitude and Implications for Action. World Bank Staff Working Paper 741.

http://documents.worldbank.org/curated/en/958551468768269528/pdf/multi0page.pdf

Ley, E. (2010). Fiscal (and External) Sustainability. Economic Policy and Debt Department, PREM, The World Bank.

Mustapha, S., \& Prizzon, A. (2015). Debt Sustainability and Debt Management in Developing Countries. Economic and Private Sector Professional Evidence and Applied Knowledge Service Topic Guide. London: Overseas Development Institute.

Mustapha, S., \& Prizzon, A. (2018). Africa's Rising Debt: How to Avoid a New Crisis. Briefing Note. London: Overseas Development Institute.

Olabisi, M., \& Stein, H. (2015). Sovereign Bond Issues: Do African Countries Pay more to Borrow? Journal of African Trade, 2, 87-109. https://doi.org/10.1016/j.joat.2015.08.003

Parker, K., \& Kastner, S. (1993). A Framework for Assessing Fiscal Sustainability and EXternal Viability, with an Application to India. Working Paper 93/78, Washington DC: International Monetary Fund. https://doi.org/10.5089/9781451850055.001

United Nations Economic Commission on Africa (UNECA) (2015). Report of the High Level Panel on Illicit Financial Flows from Africa.

United Nations Economic Commission on Africa (UNECA) (2019). Fiscal Policy for Financing Sustainable Development in Africa. Economic Report for Africa. 


\section{Appendix}

Table A1. Percentage of the debt of African countries' debt to GDP.

\begin{tabular}{|c|c|c|c|c|c|c|}
\hline & $2000-2002$ & 2003-2005 & 2006-2008 & $2009-2011$ & $2012-2014$ & 2015-2017 \\
\hline Africa & 104.47 & 90.84 & 56.94 & 42.53 & 41.80 & 56.58 \\
\hline Algeria & 56.11 & 34.54 & 15.07 & 9.84 & 8.20 & 18.88 \\
\hline Angola & 107.05 & 46.38 & 23.72 & 41.01 & 33.22 & 67.10 \\
\hline Benin & 49.36 & 32.74 & 18.66 & 28.07 & 27.48 & 48.85 \\
\hline Botswana & 7.93 & 8.21 & 6.51 & 19.56 & 17.97 & 15.62 \\
\hline Burkina Faso & 48.67 & 44.85 & 24.64 & 29.31 & 29.13 & 37.73 \\
\hline Burundi & 140.97 & 160.56 & 120.79 & 38.44 & 37.77 & 48.47 \\
\hline Cabo Verde & 81.70 & 83.48 & 66.71 & 72.14 & 103.18 & 126.10 \\
\hline Cameroon & 68.45 & 53.28 & 15.41 & 14.14 & 18.39 & 33.81 \\
\hline Central African Rep. & 98.90 & 105.12 & 45.10 & 21.45 & 43.74 & 57.61 \\
\hline Chad & 59.62 & 35.26 & 22.70 & 30.72 & 33.61 & 49.19 \\
\hline Comoros & 91.10 & 71.72 & 61.64 & 50.03 & 27.50 & 27.91 \\
\hline Congo, Dem. Rep. & 150.88 & 119.23 & 93.90 & 50.46 & 19.70 & 18.08 \\
\hline Congo, Rep. & 179.77 & 170.44 & 96.24 & 64.04 & 51.47 & 121.54 \\
\hline Cote d'Ivoire & 95.90 & 78.91 & 74.76 & 65.48 & 44.40 & 48.50 \\
\hline Djibouti & 60.01 & 64.01 & 58.42 & 52.21 & 43.64 & 65.74 \\
\hline Egypt, Arab Rep. & 78.87 & 97.29 & 76.32 & 70.62 & 80.98 & 96.15 \\
\hline Equatorial Guinea & 27.18 & 4.69 & 0.82 & 6.47 & 8.64 & 38.35 \\
\hline Eritrea & 180.84 & 170.97 & 161.14 & 140.27 & 128.16 & 132.18 \\
\hline Eswatini & 18.49 & 14.96 & 14.70 & 12.81 & 14.46 & 24.77 \\
\hline Ethiopia & 99.44 & 95.01 & 52.80 & 41.21 & 45.84 & 56.52 \\
\hline Gabon & 78.18 & 59.96 & 32.96 & 22.90 & 28.87 & 57.18 \\
\hline The Gambia & 77.50 & 81.58 & 54.16 & 42.73 & 59.08 & 79.61 \\
\hline Ghana & 66.26 & 42.62 & 22.06 & 30.99 & 43.32 & 56.40 \\
\hline Guinea & 88.18 & 88.78 & 71.50 & 62.72 & 32.08 & 41.45 \\
\hline Guinea-Bissau & 226.72 & 218.52 & 181.52 & 91.02 & 50.96 & 55.94 \\
\hline Kenya & 56.76 & 54.09 & 41.27 & 42.85 & 45.47 & 53.15 \\
\hline Lesotho & 91.31 & 48.75 & 48.95 & 33.20 & 38.25 & 39.09 \\
\hline Liberia & 399.52 & 466.76 & 301.18 & 51.50 & 19.06 & 29.43 \\
\hline Madagascar & 103.94 & 93.82 & 34.28 & 35.49 & 35.42 & 39.29 \\
\hline Malawi & 137.21 & 116.73 & 30.91 & 31.98 & 52.64 & 61.48 \\
\hline Mali & 70.22 & 44.40 & 18.96 & 23.73 & 26.38 & 34.02 \\
\hline Mauritania & 223.50 & 167.88 & 69.95 & 57.70 & 54.86 & 77.39 \\
\hline Mauritius & 60.39 & 62.75 & 53.81 & 57.05 & 59.25 & 65.09 \\
\hline
\end{tabular}




\section{Continued}

\begin{tabular}{ccccccc}
\hline Morocco & 66.62 & 59.93 & 50.39 & 49.22 & 60.53 & 64.55 \\
Mozambique & 105.79 & 68.27 & 39.63 & 41.08 & 51.86 & 104.27 \\
Namibia & 22.03 & 27.10 & 20.62 & 19.22 & 24.20 & 39.91 \\
Niger & 106.11 & 70.12 & 21.45 & 22.72 & 26.74 & 44.14 \\
Nigeria & 51.32 & 32.17 & 8.27 & 11.93 & 17.94 & 23.03 \\
Rwanda & 103.04 & 83.73 & 22.23 & 18.03 & 22.08 & 33.03 \\
Sao Tome \& Principe & 386.26 & 322.91 & 144.00 & 76.66 & 73.88 & 89.07 \\
Senegal & 55.91 & 38.96 & 18.23 & 29.29 & 37.77 & 50.94 \\
Seychelles & 191.16 & 161.42 & 157.07 & 90.29 & 73.67 & 66.65 \\
Sierra Leone & 169.74 & 147.61 & 62.59 & 46.55 & 34.09 & 52.66 \\
South Africa & 40.05 & 34.34 & 28.31 & 34.33 & 44.03 & 51.27 \\
Sudan & 130.19 & 96.88 & 57.72 & 69.24 & 91.09 & 101.67 \\
Tanzania & 48.64 & 45.22 & 25.32 & 26.51 & 30.47 & 36.30 \\
Tunisia & 58.26 & 53.88 & 44.92 & 40.99 & 48.68 & 62.68 \\
Uganda & 66.87 & 63.43 & 26.12 & 21.67 & 27.66 & 37.02 \\
Zambia & 217.15 & 121.70 & 22.04 & 20.07 & 29.55 & 61.88 \\
Zimbabwe & N/A & 33.06 & 48.39 & 51.00 & 38.68 & 49.61 \\
\hline
\end{tabular}

Source: Authors' calculations based on data from World Bank. 